\title{
Impacts of Six-Hats Critical Thinking Skills on the Achievement and Retention in Chemistry Among Secondary School Students in Niger State, Nigeria for Sustainable Development
}

\author{
CHADO, Amina Mohammed (PhD)*, WUSHISHI, Dantani Ibrahim (PhD); IDRIS, Aisha Ozohu and BABAGANA, \\ Mohammad( $\mathrm{PhD})$ \\ Department of Science Education, School Of Science and Technology Education, Federal University of Technology, Minna, \\ Nigeria \\ Corresponding Author*
}

\begin{abstract}
This study investigated the Impact of Six-hats Critical Thinking Skills on Achievement and Retention in Chemistry. Among Secondary Schools Students of Niger State, Nigeria. A pre-test, post-test control group non-randomize non -equivalent control group quasi experimental design was adopted. Four research questions were raised and four hypotheses were formulated and tested at $\mathbf{0 . 0 5}$ level of significance. Four schools were randomly selected using simple random sampling technique. The population of the study comprises all senior secondary school two (2) chemistry students in Chanchaga Local Government Area of Niger state. A total of (161) student participated in the study using intact classes. The instruments used for data collection was Chemistry Achievement Test (CAT). The face and content validity of CAT were determined by experts in department of science education . The reliability coefficient of 0,81 was obtained using Kuder-Richardson (KR20) method. Data collected were analyzed using mean, standard deviation and t-test. The result shows that the group taught with SHTIP (experimental group) performed better than the one taught using conventional lecture method. Gender achievement of students did not differ significantly It was recommended that activities that allow students to think multi-directionally should be supported to ensure better comprehension of abstract Chemistry topics.
\end{abstract}

Key words: six hats of critical thinking, achievement

\section{INTRODUCTION}

$\mathrm{T}$ he objectives of Chemistry curriculum at the senior secondary school level include to show Chemistry and its link with industry, everyday life benefits and hazards, and to provide a course which is complete for individuals not proceeding to higher education. (NPE,20013).Without effective Chemical education, our nation will likely remain impoverished. This is because the natural resources which abound in Nigeria need to be harnessed, processed and converted to needed products for sustainable development.(Adikwu, 2010)

However, for Nigeria to achieve sustainable development there is the need to trained students in Chemistry that will utilized the knowledge acquired to utilized and harnessed this mineral resources. It is in line with this claim that Njoku (2009) maintains that Chemistry teachers are under intense pressure to cover the syllabus and get students ready for external examinations. This makes the objectives of teaching and learning Chemistry difficult to be achieved as the teachers adopt teaching conventional lecture methods that allows for easy coverage of the syllabus thus resulting in poor performance in external examination(Ezeliora2003).It is against this backdrop that $\mathrm{Nnaka(2006)}$ suggested adopting innovative approaches to teaching and learning Chemistry which allows students to think in a multidirectional way for better understanding of Chemistry concepts. One of such concepts is the six-hats of critical thinking. skills

The six-hat critical thinking is a type of cooperative learning developed by Edward de Bono in1987. It is a strategy used to promote parallel thinking and to help students look at a problem or decision from many different perspectives. It is used in education and a variety of industries and businesses for training and decision making. The six-hats critical thinking skill strategy uses the metaphor of "put on your thinking hat" to mimic a change of thought processes as one puts on or takes off a hat. The hat is made up of six colours and each colour of the hat represents a specific area to focus to consider ranging from looking at topic foreside as, from a neutral and objective perspective, while taking an alternative perspective, with opportunity in mind, while focusing on emotions, or to consider the overall issue at hand (de Bono, 1987). .

Studies conducted on the effects of six-hats of critical thinking skills reveals that improves students reactivity innovations and fosters collaborative thinking which leads to better achievement (Chen,2000;Gonzalez et al,2001; and Semor et al,2003)

In agreement with this Horsfall and Bennett(2005) conducted a study on the use of six-hats of critical thinking skills in the 
listening and speaking skills of pupils of IV class. Findings revealed that there are positive outcomes such as improvement in speaking and listening skills, development of effective collaboration as well as increased motivation among the pupils.. Sinclair et al (2005) also revealed that by using the Six Thinking Hats and Drama techniques, there is a real impact on students' performance and a positive change in their attitudes towards writing skills. Another study was carried by Govender (2005) on the effects of six thinking hats critical thinking of high school students. The results showed that this strategy is helpful in enhancement of different types of critical thinking skills and creates visual metaphors when analyzing a novel. Paterson (2006) in another on the effects of the strategy applied to mathematics education in the primary classroom observed that it improves the pupils achievement in the area of meta cognition and meta computation in Mathematics .

The six hats of critical thinking which consistent elaboration of learning concepts provides students who either receive the explanation or those who give the explanation with a deep understanding and a more complete retention of the concepts being learnt for a longer period of time.(Tanel \& Erol, 2008; Moore, 2008; Sahin, 2010).The six hats of critical thinking have also been observed to be gender friendly irrespective of either male or female.(Igbo 2004).Therefore this study examined and determined the effects of six hats of critical thinking skills on the achievement and retention of senior secondary schools students in Chemistry in Niger State, Nigeria.

\section{Statement of the Problem}

The uniqueness of Chemistry makes it occupy a pride of place in the scientific and technological development of any nation. Unfortunately, Chemistry is widely perceived as abstract and difficult by students. This however may be attributed to the way the teachers exposed the students to this concepts in class using the conventional lecture method thus the students result to rote learning (Boujaoude and Barakat, 2000). The conventional teaching methods have been observed to lack the adequacy of motivation, does not give students the opportunity to think in multi direction, student's and interaction required for effective learning of Chemistry concepts students face in the course of their of senior secondary education. Enough cooperation and interactions among students are required for over learning and transfer of learning in Chemistry concepts, which are usually more difficult, and abstract (Nzewi, 2010). Therefore this study examined the effects Six-Hats of Critical thinking skills on student achievement in Chemistry among senior secondary school student in Niger State Nigeria.

\section{Objectives}

The following objectives was achieved in the study
1. To determine the impact of Six-Hats of Critical thinking skills on students achievement in Chemistry

2. To determine the impact of Six-Hats of Critical thinking skills on students' retention in Chemistry

\section{Research Questions}

The following research questions were raised to guide this study:

1. Is there any difference between the mean scores of students taught Chemistry using Six-Hats of Critical thinking skills and those with conventional lecture method?

2. Is there any difference between the mean achievement scores of male and female students taught Chemistry using Six-Hats of Critical thinking skills?

3. Is there any difference between the mean posttest scores and retention scores of students taught using Six-Hats of Critical thinking skills?

4. Is there any difference in the mean retention scores in Chemistry between the male and female students taught Chemistry using Six-Hats of Critical thinking skills?

\section{Research Hypotheses}

The following null hypotheses were tested at 0.05 level of significance

$H O_{l}$. There is no significant difference between the mean scores of students taught Chemistry using Six-Hats Critical thinking skills and those taught with conventional lecture method

$\mathrm{HO}_{2}$ : There is no significant difference between the mean achievement scores of male and female students taught Chemistry using Six-Hats Critical thinking skills.

$\mathrm{HO}_{3}$ : There is no significant difference between the mean posttest scores and retention scores of students taught using Six-Hats of Critical thinking skills?

$\mathrm{HO}_{4}$ : There is no significant difference in the mean retention scores in Chemistry between the male and female students taught Chemistry using Six-Hats of Critical thinking skills?

\section{METHODOLOGY}

The study adopted a pre-test, post-test, non-randomize non equivalent control group quazi experimental design. Four research questions were raised and four hypotheses were formulated and tested at 0.05 level of significance. The population of the study comprises all senior secondary school two (2) chemistry Students in Chanchaga Local Government Area of Niger state, Nigeria. Four schools were randomly selected using simple random sampling technique. A total of 161 students participated in the study. The instruments used for data collection was Chemistry Achievement Test (CAT). The face and content validity of the CAT were determined by 
experts in science education in the department of science education Federal University of Technology, Minna. A reliability coefficient of 0.81 using Kuder-Richardson (KR-20) method was adopted. Data collected was analyzed using mean, standard deviation and t-test.

\section{RESULTS}

Table 1: t-test of the pretest scores of experimental and control groups

\begin{tabular}{|c|c|c|c|c|c|c|c|}
\hline & Group & $\mathrm{N}$ & $\mathrm{Df}$ & $\begin{array}{c}\text { Mea } \\
\mathrm{n}\end{array}$ & $\begin{array}{c}\text { Std. } \\
\text { Deviati } \\
\text { on }\end{array}$ & t-value & Sig. \\
\hline $\begin{array}{c}\text { PRE } \\
\text { TES } \\
\mathrm{T}\end{array}$ & $\begin{array}{c}\text { Experime } \\
\text { ntal }\end{array}$ & 77 & 159 & 7.40 & 3.019 & 0.791 & 0.430 \\
\cline { 2 - 8 } & Control & 84 & & 7.79 & 3.116 & & \\
\hline
\end{tabular}

Ns - Not Significant at $\mathrm{p}>0.05$

Table1 shows the t-test value on pretest achievement scores of the experimental and control groups $\mathrm{t}(159)=0.791, \mathrm{p}$ $>0.05$ This shows that the groups were equivalent as regards entry behavior.

$\left(\mathrm{HO}_{1}\right)_{\text {: }}$ There is no significant difference between the mean scores of students taught Chemistry using Six-Hats of Critical thinking skills and those taught with conventional lecture method

Table 2: t-test of the posttest scores of the experimental and control groups

\begin{tabular}{|c|c|c|c|c|c|c|c|}
\hline & Group & $\mathrm{N}$ & $\mathrm{Df}$ & $\begin{array}{c}\text { Mea } \\
\mathrm{n}\end{array}$ & $\begin{array}{c}\text { Std. } \\
\text { Deviati } \\
\text { on }\end{array}$ & $\begin{array}{c}\mathrm{t}- \\
\text { valu } \\
\mathrm{e}\end{array}$ & $\begin{array}{c}\text { Sig.2 } \\
\text { taile } \\
\mathrm{d}\end{array}$ \\
\hline \multirow{3}{*}{$\begin{array}{c}\text { POST } \\
\text { TEST }\end{array}$} & $\begin{array}{c}\text { Experi } \\
\text { mental }\end{array}$ & 77 & 159 & $\begin{array}{c}12.2 \\
1\end{array}$ & 3.304 & $\begin{array}{c}4.20 \\
2\end{array}$ & 0.00 \\
\cline { 2 - 8 } & Control & 84 & & $\begin{array}{c}10.0 \\
3\end{array}$ & 3.297 & & \\
\hline
\end{tabular}

*- Significant at $\mathrm{p}<0.05$

The table shows the results of the mean posttest scores of students taught Chemistry using Six-Hats Critical thinking skills and those taught with conventional lecture method $\mathrm{t}(159)=4.202, \mathrm{p}<0.05$. Therefore, the null hypothesis was rejected, thus there is significant difference between the mean scores of students taught Chemistry using Six-Hats of Critical thinking skills and those taught with conventional method.

\section{Hypothesis $\mathrm{Two}\left(\mathrm{HO}_{2}\right)$}

There is no significant difference between the mean achievement scores of male and female students taught Chemistry using Six-Hats Critical thinking skills.

Table 3: t-test of the posttest scores of male and female students taught usingSix-Hats Critical thinking skills

\begin{tabular}{|c|c|c|c|c|c|c|c|}
\hline & Group & $\mathrm{N}$ & Df & Mean & $\begin{array}{c}\text { Std. } \\
\text { Deviat } \\
\text { ion }\end{array}$ & $\begin{array}{c}\mathrm{t}- \\
\text { valu } \\
\mathrm{e}\end{array}$ & $\begin{array}{c}\text { Sig.2ta } \\
\text { iled }\end{array}$ \\
\hline \multirow{2}{*}{$\begin{array}{c}\text { POST } \\
\text { TEST }\end{array}$} & Males & 36 & 75 & 9.83 & 3.645 & .478 & .634 \\
\cline { 2 - 8 } & Females & 41 & & 10.20 & 2.993 & & \\
\hline
\end{tabular}

Ns - Not Significant at $\mathrm{p}>0.05$
Table3. shows the $t$ value of the gender difference in the use of Six-Hats of Critical thinking skillst $(75)=0.478, \mathrm{p}>$ 0.05 ..Hence, the null hypothesis was retained as there was no significant difference between the mean achievement scores of male and female students taught Chemistry using six-hats of critical thinking skills.

Table4: Paired t-test of the difference in the retention scores of the experimental group

\begin{tabular}{|c|c|c|c|c|c|c|}
\hline TESTS & $\mathrm{N}$ & Df & $\begin{array}{c}\text { Mea } \\
\mathrm{n}\end{array}$ & $\begin{array}{c}\text { Std. } \\
\text { Deviati } \\
\text { on }\end{array}$ & t-value & $\begin{array}{c}\text { Sig.2tail } \\
\text { ed }\end{array}$ \\
\hline Posttest & 77 & 76 & $\begin{array}{c}11.2 \\
1\end{array}$ & 3.297 & 1.000 & 0.320 \\
\hline Retention & 77 & & $\begin{array}{c}10.3 \\
2\end{array}$ & 3.248 & & \\
\hline
\end{tabular}

Ns - Not Significant at $\mathrm{p}>0.05$

Table 4 shows paired t-test results of the mean difference of posttest and retention scores of the experimental group. $t(76)$ $=1.000, \mathrm{p}>0.05$. Therefore, it is evident that there was no significant difference between the mean posttest scores and retention scores of students taught using Six-Hats of Critical thinking skills

$\mathrm{HO}_{4}$. There is no significant difference in the mean retention scores in Chemistry between the male and female students taught Chemistry using Six-Hats of Critical thinking skills.

Table 5: t-test of the difference in the mean retention scores of males and females of experimental group

\begin{tabular}{|c|c|c|c|c|c|c|c|}
\hline & $\begin{array}{c}\text { GEN } \\
\text { DER }\end{array}$ & $\mathrm{N}$ & Df & $\begin{array}{c}\text { Me } \\
\text { an }\end{array}$ & $\begin{array}{c}\text { Std. } \\
\text { Deviati } \\
\text { on }\end{array}$ & $\begin{array}{c}\text { t- } \\
\text { value }\end{array}$ & $\begin{array}{c}\text { Sig.2tail } \\
\text { ed }\end{array}$ \\
\hline RET \\
$\begin{array}{c}\text { ENTI } \\
\text { ON }\end{array}$ & $\begin{array}{c}\text { Male } \\
\text { Sema }\end{array}$ & 36 & 75 & $\begin{array}{c}9.7 \\
2\end{array}$ & 0.590 & .478 & .527 \\
\hline
\end{tabular}

Ns - Not Significant at $\mathrm{p}>0.05$

Table 5 reveals the t-test results of the gender difference in the mean retention scores of the experimental group $\mathrm{t}(75)=0.478$, $\mathrm{p}>0.05$. Hence, the null hypothesis was retained as no significant difference in the retention in Chemistry between the male and female students taught Chemistry using Six-Hats of Critical thinking skills was identified.

\section{DISCUSSION}

The results of the study revealed that students in the experimental group had higher academic achievement than those in the control group. The improved achievement in the experimental group may be attributed to the fact that students in the experimental group were actively involve in the learning process which allows the students to think in a multidimensional way. The findings of this study is in agreement with the result of Nnaka (2006) and Tooley (2009) who found that six -hats of critical thinking improves students achievement in speaking and listening skills in learning in English Language. The result also revealed that students in the experimental group also have greater 
retention of information than those in the control group. This may be attributed to the treatment given to the experimental group. The result of this findings is in agreement with the results of some earlier studies (Johnson \& Johnson, 2005; Tanel \& Erol, 2008; Moore, 2008; Sahin, 2010)

Findings from the study also revealed that there is no significant difference in achievement in terms of gender differences. This implies that both males and females benefited equally well from the treatment. This is in line with the findings of Igbo (2004) who maintains that instructional approaches neither favour nor disfavour a particular sex in achievement.

\section{CONCLUSION}

Findings form this study shows that using the Six-Hats of critical thinking skills ensures greater achievement of students than the conventional lecture method in Chemistry classes.

\section{RECOMMENDATION}

Based on the finding of the study, the following recommendation were made

1. Chemistry teachers should be encouraged to adopt innovative teaching strategies such as six- hats of critical thinking skills that encourage students to think multi-directionally

2. Chemistry teachers should be encouraged to attend in workshops, seminars and conferences to update their knowledge and skills to promote their professional development

3. School administrators should encourage and monitor Chemistry teachers' and students' instructional activities

\section{REFERENCE}

[1] Adiukwu, M.U (2010) Challenges of scientific research in Nigeria. Paper presented at the conference/annual award of the Chemical Society of Nigeria, Anambra state chapter College of Education (Technical), Umunze.

[2] Ahmed, M. A., Abimbola I.O., Omosewo, E. O. and Akanbi, A. O. (2012). Availability and Utilization of Instructional Resources for Teaching Basic Science and Technology in Secondary Schools in
Ilorin, Nigeria. 53 ${ }^{\text {rd }}$ Annual ConferenceProceedings of Science Teachers Association of Nigeria.

[3] Boujaoude, S. \&Barakat, H. (2000). Secondary school students' difficulties with stoichiometry. School Science Review. 81, 9198.

[4] De Bono, E. (1987). Six thinking hats. London: Penguin

[5] De Bono E. (2004). "Six Thinking Hats (Technique)." http://members.Ozemaicoml.Au/caveman / Creative /Techniques/sixhats.html.

[6] Ezeliora, B (2003) problems affecting the effectiveness use of information technology in teaching and learning of chemistry in schools in Nigeria. 44th anual conference proceeding of science teachers association of Nigeria (pp139 -141).

[7] Federal Ministry of Education (2007) Senior secondary education curriculum Chemistry for ss1-3. Abuja, Nigerian Education Research and Development Council.

[8] Gross, R., (1998). Peak Performance: The SixHats, Armed Forces Comptrollers, 34 (3), 38

[9] Igbo, J.N. (2004) Effect of peer tutoring on the mathematics achievement of learning disabled children. Unpublisheddoctoral thesis, faculty of education, University of Nigeria Nsukka.

[10] Johnson, D. W., Johnson, R. T., \& Smith, K. A. (1991). Active learning: Cooperation in the college classroom. Edina, MN: Interaction.

[11] Johnson, D. W., Johnson R. T., \&Stanne, M. (2000). Cooperative learning methods: A meta-analysis. Running Head: Cooperative Learning Methods, 2-12

[12] Kasalta K, Tzougraki C 2004. Attitudes toward Chemistry among 11 th grade students in high schools in Greece. Science Education, 88(4): 535-547.

[13] Learning Things LLC 2014. Teaching Chemistry to Middle School Students- Huge Selection of School and Homeschool Curriculum. From <https://www. learningthings.com/blog/index.php> (Retrieved on 2 October 2017).

[14] Nnaka, C.V. (2006) Innovative strategies for effective teaching and learning of science, technology and mathematics (STM) in schools. Paper presented at the workshop by science teachers Association of Nigeria, Awka.

[15] Nzewi, U,M. (2010). It's all in the brain of gender and achievement in science and technology education. 51st Inaugural Lecture of the University of Nigeria, Nsukka.

[16] Samba, R. M., Achor, E. E., \&Ogbeba, J. A. (2010). Teachers"e awareness and utilization of innovative teaching strategies in secondary school science in Benue State, Nigeria ,Educational Research, 1(2), 32-38. Retrieved March, 2016. http://www.interesjournals.org/ER

[17] Siegel, C. (2005). Implementing a research based model of cooperative learning. The Journal of Educational Research. 98 (6). $1-15$.

[18] Slavin, R. E. (1995). Cooperative Learning. Needham Heights, MA: Simon \& Schuster 